\title{
VALUATION OF A COMMUNITY COMPANY AND ITS IMPACT ON DEVELOPMENT STRATEGIES
}

\author{
BETHY MERCHAN ${ }^{1,2,3}$, ROMINA TORRES ${ }^{1,2}$, JANNELY BENALCAZAR ${ }^{1,2}$, PAÚL CARRIÓN-MERO $^{1,2}$, \\ GRICELDA HERRERA-FRANCO ${ }^{3,4}$, EDGAR BERREZUETA ${ }^{5}$ \& MARÍA JAYA-MONTALVO ${ }^{6}$ \\ ${ }^{1}$ Faculty of Engineering in Earth Sciences (FICT), Escuela Superior Politécnica del Litoral (ESPOL), Ecuador \\ ${ }^{2}$ Center for Research and Projects Applied to Earth Sciences (CIPAT), \\ Escuela Superior Politécnica del Litoral, Ecuador \\ ${ }^{3}$ Geo-Resources and Applications (GIGA), Escuela Superior Politécnica del Litoral, Ecuador \\ ${ }^{4}$ Faculty of Engineering Sciences, Santa Elena Peninsula State University (UPSE), Ecuador \\ ${ }^{5}$ Departamento de Infraestructura Geocientífica y Servicios, \\ Instituto Geológico y Minero de España (IGME), Spain \\ ${ }^{6}$ Junta Administradora de Agua Potable Regional de Manglaralto (JAAPMAN), Ecuador
}

\begin{abstract}
Water and sanitation are basic and essential rights for the adequate development of a population. In the context of the rural area studied in this work (Manglaralto, Ecuador), at the beginning of 1979 the Manglaralto Potable Water Board (JAAPMAN) was registered with the objective of managing the water supply in the area. This board is administered by local users, under the principles of joint work, local democracy, and self-management. Currently, the service provided reaches 26,362 people. JAAPMAN, during the 40 years that it has been operating non-profit, has generated significant assets in its operating infrastructure. With the creation of the Ministry of Environment and Water in Ecuador, there is the possibility that the community company will become managed by a public water company. This situation could cause conflicts and mistrust in society since the community has self-managed and solved its water supply for 40 years. This article aims to develop an inventory of physical infrastructure, equipment, machinery, plus operation and maintenance expenses, of the investment that has been made to date, to quantify its value and, more generally, estimate the company's expenses. In this context, the method considers the following: (i) preparation of inventory tables; (ii) estimate of the value of assets, other income and general expenses; and (iii) proposal for development strategies. The most relevant result is that it indicates that the accumulated equity of the community enterprise is approximately two million dollars, which shows the good management carried out to date and, in addition, the possibility of obtaining international financing and support. Finally, it was revealed that joint work in the company is constantly evolving and is executed efficiently and effectively.
\end{abstract}

Keywords: community enterprise, assets, business efficiency, development strategies.

\section{INTRODUCTION}

The value of a company could be defined as a measure of the evaluation of the activity of that company. This value is a key characteristic and its analysis is essential because the ability to evaluate the effects of the company's operation in the market is the fundamental strength of the company [1]. In addition, the value of a company is one of the important topics highlighted by stakeholders, such as investors, managers, employees, customers or suppliers. However, it is important to comment that to this day, discussions continue on the concept of business value or measurement of value [2]-[4]. According to [5], traditional business valuation methods are based on the balance sheet, the income statement or the cash flow statement; however, intellectual capital is also an asset. As indicated [6], it is an asset market and the book value could not be explained because the intellectual capital is zero. According to [7], intellectual capital is intangible and is made up of all the non-financial assets of a company, which are not reflected in the balance sheet.

In addition to traditional companies, so-called community companies can and should also be valued. Community companies are created based on the needs of the population to manage 
services that are not provided in a timely manner by the state or a private company. The study of community management has been the subject of various theoretical analyzes in the last five decades [8]. In the 1970s, the observation of community management as a rural phenomenon began. In the 1980s, under the social capital approach (an initiative sponsored by the World Bank), community management was promoted as a scenario for strengthening the social fabric [9]. This trend continues to be applied in current empowerment approaches. In the 90s, starting from the theory of common goods, the archetype of the classical economy based on the interaction of the individual-society-state in a competitive environment was questioned, in order to present new alternatives of governance supported by the recognition of the community as collaborative collectivity and the possibility of human interaction under rules of cooperation [10]. Since the mid-1990s, collaborative management or co-management recovers the value of the interaction between actors or stakeholders in which individuals (as an expression of individual initiative), communities (as an expression of collective action), local, regional and national governments and other civil society organizations take part in the management of resources and services. In general, it can be said that the community management has been a traditional form of governance of natural resources in peasant and indigenous communities [11], currently being part of the society and culture of rural and urban-marginal areas.

In Ecuador's case, the 2008 Constitution of the Republic of Ecuador establishes two types of management: community and public. In addition, it establishes that public-community alliances should be made to strengthen community management [12]. According to the 2010 Population Census, there are about 14 million inhabitants of that total, 5 million live in rural areas, of which approximately 3.5 million have access to water through community management [13]. In the Manglaralto parish, approximately 26,362 people receive water resources from groundwater wells. The Manglaralto Regional Drinking Water Administration Board (JAAPMAN) makes an effort to manage drinking water in six communes, Libertador Bolívar, Cadeate, Rio Chico, Manglaralto, San Antonio and Montañita, through the drilling of wells, construction of dikes, distribution networks and reservoirs [14], [15].

The need for the creation of this Water Board is due to the lack of vital liquid in the area, which is characterized by being a semi-arid region [16], [17], adding to the fact that it presents other problems such as the growing demand for water, being a site with a high influx of tourists and the phenomenon of saline intrusion [18]. In this context, in search of sustainability [19], new studies have been developed, such as the creation of green filter systems in the Montañita commune [20], hydrochemical studies [18], flow model [21], watershed integral management [22] and even geotourism potential [23] as it is a socioecological system [24] with rescue practices of ancestral knowledge [22].

With the creation of the Ministry of the Environment and Water in Ecuador, there is a risk and the possibility that JAAPMAN will be managed by a central government company. This situation could cause conflicts and mistrust in society since the community has selfmanaged and solved its water supply for 40 years, therefore, it is necessary to quantify its accumulated patrimony as a reflection of the effort, dedication and joint work developed.

The main aim of this research is, to prepare the inventory of the assets of a community company and, mainly, to give an economic valuation to the movable and immovable property of the Manglaralto Board. In addition, it is proposed to address a general estimate of expenses. With the global valuation data, the configuration of management strategies and future development of JAAPMAN will be presented. 


\section{METHODOLOGY}

In this work, three main phases have been considered for the development of research (Fig. 1).

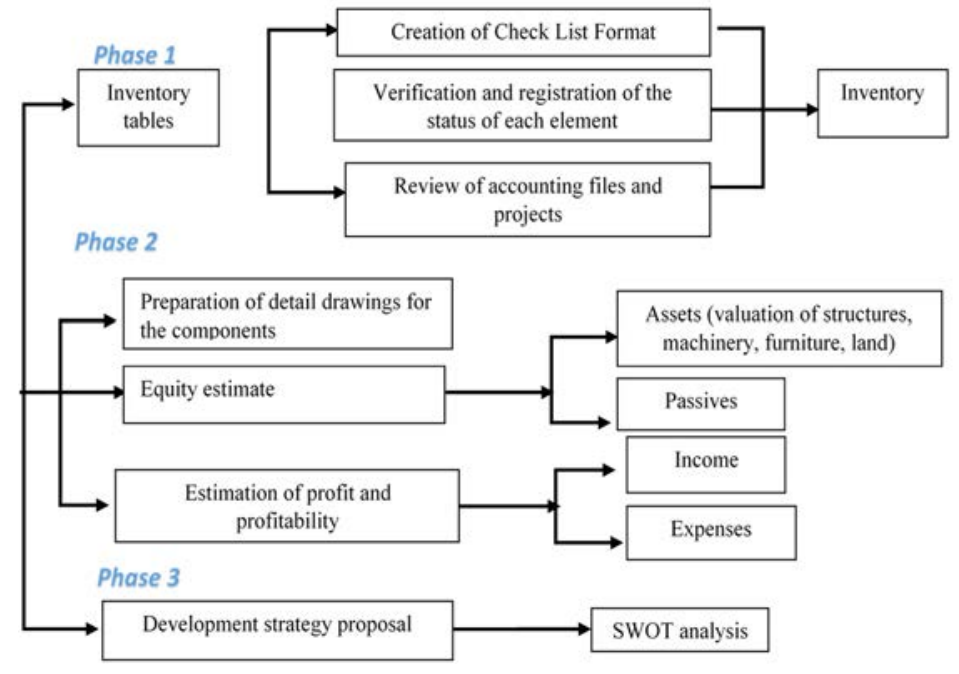

Figure 1: Scheme of steps to follow during the analysis of community business assets.

The first phase focused in detail on the creation of inventory tables: check list, verification and registration of the status of each element by component and review of accounting files and project information. In addition, the physical formats, inventory tables for wells, dams and reservoirs were created in the office, which contain all the detailed compilation of: (a) year of construction, (b) locations referenced with GPS, (c) records of the names of the elements of each component with their respective quantities, brands and states of functionality. All this in order to have an information base of the elements of each infrastructure, equipment, machinery and building, to be able to quantify, verify, value and reference each of its components managed by JAAPMAN. With the form ready, the field investigation was programmed, where the tours of the different components were carried out, and the types of investment infrastructures of the JAAPMAN could be physically verified. In each one of them a technical sheet was configured. Additionally, the files with technical specifications of the equipment and its maintenance were reviewed. The form fields were filled out, verifying and searching for the pertinent information. The files were reviewed in the JAAPMAN offices where documents of purchases and acquisitions of materials and equipment were verified. Equipment and materials without physical documentation support were valued with input from the different projects. The implementation of improvements and maintenance to the infrastructures through the self-management of JAAPMAN was also considered.

The second phase was initially focused on the development of detail plans and calculation of current economic value from the field survey where the information was collected for the preparation of the plans for each component belonging to JAAPMAN. Next, the detailed plans were made that contain, (a) plan of the type of well; (b) wells and dikes location plan; (c) general scheme of distribution networks; where you can view the references of dikes, wells and reservoirs. With this information, the referential budget for each well, dam, 
reservoir, distribution networks and administrative office was configured. Quantities were calculated working for each item with its respective analysis of unit price (APU). Wear was considered due to the elapsed time of each element, an inspection was carried out to determine the status, functioning and remaining useful life, as well as to define the economic value that would correspond to it due to depreciation. Once the depreciation, maintenance and improvement concepts have been obtained, the total investment of the JAAPMAN is calculated. It is important to note that once the referential budget for the structures had been obtained, it was necessary to carry out a depreciation using the Ross Heidecke method, which uses the Fitto and Corvini tables [25]. This type of method was necessary since it applies depreciation factors that relate the useful life and the state of conservation of the structure. For machinery and furniture, a depreciation was carried out using the decreasing method by sum of digits. In this phase, the estimation of income from collections in water supply, savings, expenses (salaries and maintenance of the infrastructures) and overdue portfolios by consulting the accounting books was also addressed. All this to be able to make a general balance of the company to obtain the current economic value.

The last and third phase focused on developing a proposal for development strategies, with all the information collected, and once the patrimony had been quantified, the proposal that JAAPMAN should implement in the short, medium and long term was drawn up. To obtain the strategies, a workshop was implemented with representatives of JAAPMAN, community members, and technicians linked to JAAPMAN activities, with which the analysis of strengths, opportunities, weaknesses and threats (SWOT) was carried out.

\section{RESULTS}

\subsection{Creation of check list formats and general inventory}

These formats allowed the gathering of information for the inventory of the elements of the company (e.g. structures). They were made in digital format to facilitate their use and future storage. The information generated was delivered to the company for continuous and future use in economic and technical matters.

\subsection{Preparation of detailed drawings for components}

The elaboration of the detailed plans of each component (Fig. 2) allowed to define the location of the infrastructure and, mainly, its state. From this information your budget estimate was made. Information in format digital of these planes It allows its continuous updating and the incorporation of new components if necessary. In addition to the plans, a sheet was generated with the basic information for its use in component inventory.

The following steps were followed to estimate the equity:

a) Structure assessment: The inventory carried out allowed the identification of 27 infrastructures divided into 16 wells, 6 reservoirs, 3 dams, 1 distribution network and 1 company headquarters building. The information on these structures is presented in Table 1, where it is observed, year of construction, useful life and its state of conservation. In Table 2, the general assessment of the available structures is presented.

b) Machinery valuation: As machinery you have a truck and a motorcycle. To find the real present value of the machinery, it was necessary to use the decreasing depreciation method by sum of digits, which consists of applying a higher depreciation in the first 

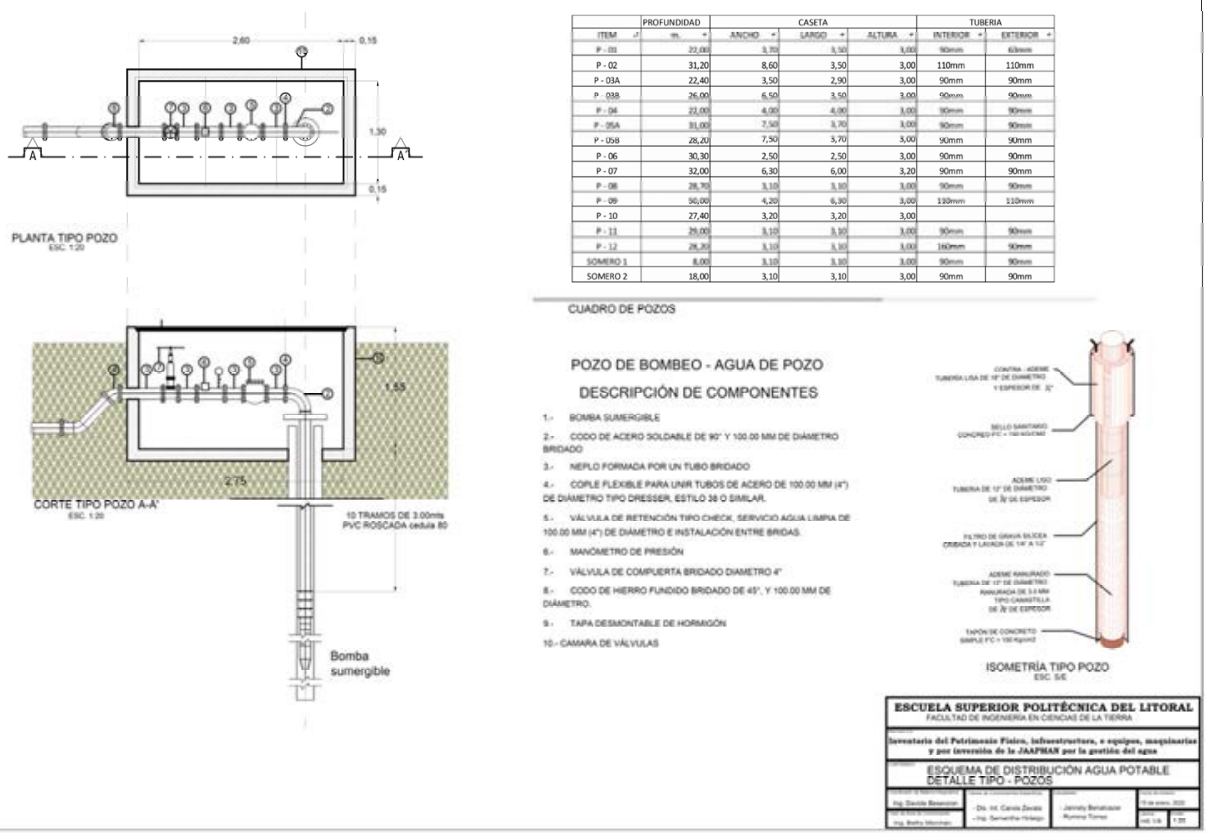

Figure 2: Typical well plan with a detailed description of its components to estimate its economic value.

years of the good's life, to decrease over the course of the asset. For the truck it was determined that the initial purchase value in 2015 was USD26,990, with a useful life of 10 years, a present value of USD 9323.82 was obtained. For the motorcycle, it was necessary to consider that its initial value was USD3090.00 purchased in 2014, with a 5year useful life, which had already been fulfilled at the date of depreciation, resulting in a value of USD 618.00.

c) Real estate value: For real estate, the office equipment was analyzed, giving a total value with replacement of USD 11,338.94 and with depreciation of USD 8,326.76.

d) Land valuation: The most of the land where JAAPMAN has its structures is not owned by it. Currently only they have deeds of five plots of $1000 \mathrm{~m} 2$ each. Obtaining a total value of USD18,467.52, data obtained with the information of the property tax payment; However, to estimate its commercial value, it was necessary to investigate the real value of the land in the area, resulting in between USD16 and USD25 the value of square meter. The lowest value was taken, USD 16.00. The global valuation of the company's land is presented in Table 3.

e) Bank savings: The JAAPMAN bank account has a savings of USD 11,000.00, according to data provided by the company to the date October 28, 2020.

f) Debts: JAAPMAN has a loan, used to buy construction materials of USD 2,500.00.

g) Equity estimation: To determine equity, it was necessary to classify the values into assets and liabilities. The estimate is presented in Table 4. 


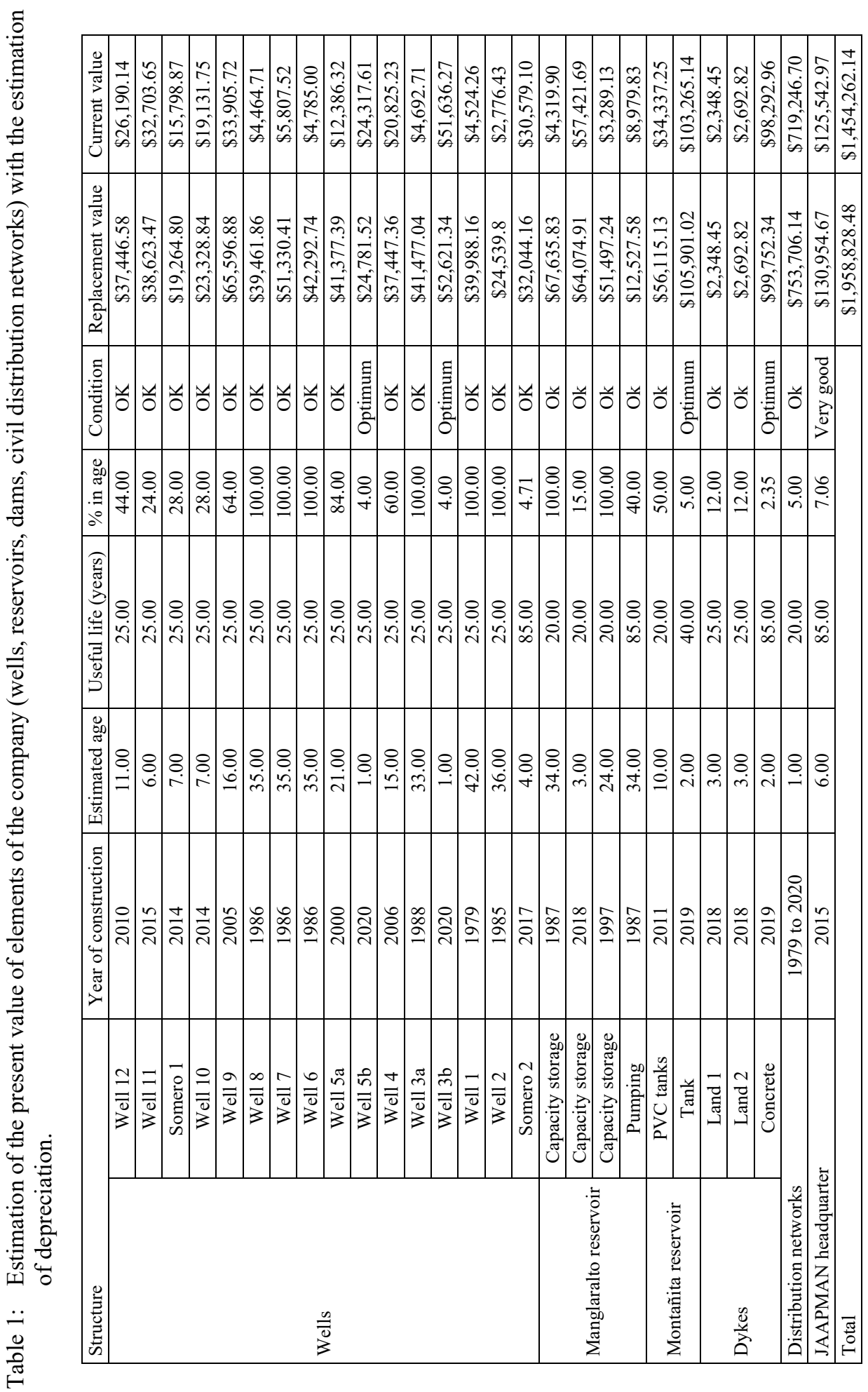


Table 2: Summary of the valuation of the structures.

\begin{tabular}{|l|c|c|}
\hline \multirow{2}{*}{ Structure } & \multicolumn{2}{|c|}{ Value } \\
\cline { 2 - 3 } & With depreciation & With replacement (USD) \\
\hline Well valuation & $294,525.29$ & $611,622.35$ \\
\hline Assessment of the Manglaralto reservoir & $74,010.55$ & $195,735.56$ \\
\hline Valuation of the Montañita reservoir & $137,602.40$ & $162,016.15$ \\
\hline Dam valuation & $103,334.23$ & $104,793.61$ \\
\hline Valuation of distribution networks & $719,246.70$ & $753,706.14$ \\
\hline JAAPMAN headquarters valuation & $125,542.97$ & $130,954.67$ \\
\hline Total & $1,454,262.14$ & $1,958,828.48$ \\
\hline
\end{tabular}

Table 3: Land valuation.

\begin{tabular}{|l|c|c|c|}
\hline Name & Area $\left(\mathrm{m}^{2}\right)$ & Property tax valuation (USD) & Commercial valuation (USD) \\
\hline Pit 9 plot & 1,000 & $4,122.25$ & $16,000.00$ \\
\hline Pit 6 plot & 1,000 & $4,081.00$ & $16,000.00$ \\
\hline Pit 5 plot & 1,000 & $4,122.25$ & $16,000.00$ \\
\hline Pit 4 field & 1,000 & $4,081.02$ & $16,000.00$ \\
\hline Pit 3 plot & 1,000 & $2,061.00$ & $16,000.00$ \\
\hline Total & 5,000 & $18,467.52$ & $80,000.00$ \\
\hline
\end{tabular}

Table 4: Equity estimation of the company.

\begin{tabular}{|l|c|c|c|}
\hline Item considered & $\begin{array}{c}\text { With replacement } \\
\text { and property tax } \\
\text { land values (USD) }\end{array}$ & With depreciation (USD) & $\begin{array}{c}\text { With replacement } \\
\text { and market land } \\
\text { values (USD) }\end{array}$ \\
\hline Land valuation & $18,467.52$ & $18,467.52$ & $80,000.00$ \\
\hline $\begin{array}{l}\text { Valuation of } \\
\text { movable property }\end{array}$ & $11,338.94$ & $8,326.76$ & $11,338.94$ \\
\hline $\begin{array}{l}\text { Equipment and } \\
\text { machinery } \\
\text { valuation }\end{array}$ & $30,080.00$ & $9,941.82$ & $30,080.00$ \\
\hline $\begin{array}{l}\text { Infrastructure } \\
\text { assessment }\end{array}$ & $1,958,828.48$ & $1,449,220.87$ & $1,958,828.48$ \\
\hline Savings in the bank & $11,000.00$ & $11,000.00$ & $11,000.00$ \\
\hline Total assets & $2,029,714.94$ & $1,496,956.97$ & $2,091,247.42$ \\
\hline \multicolumn{4}{|c|}{ PASSIVES } \\
\hline $\begin{array}{l}\text { Building materials } \\
\text { loans }\end{array}$ & $2,500.00$ & $2,500.00$ & $2,500.00$ \\
\hline \multicolumn{4}{|c|}{ Patrimony } \\
\hline Total patrimony & $2,027,214.94$ & $1,494,456.97$ & $2,088,747.42$ \\
\hline
\end{tabular}


To estimate the operational balance, the following steps were followed:

a) Income: Past due portfolio: The communes attached to the JAAPMAN have an overdue portfolio as of 2020 of USD 320,137.21. In Table 5, the debt is detailed for each commune.

Collections: To determine the collections for 40 years, data from the JAAPMAN database were used and are represented in Table 6.

b) Expenses: Expense estimate (salaries, services): To determine the total value of salaries paid by JAAPMAN for 40 years, the division of workers who have all the benefits of the law (social Security), called "affiliated workers", and the others who only received the basic salary, called "workers not affiliates". Giving as a result the data in Table 7.

Table 5: Overdue portfolio data.

\begin{tabular}{|l|r|}
\hline \multicolumn{2}{|c|}{ Past due portfolio } \\
\hline Communes & Value (USD) \\
\hline Cadeate & $27,524.50$ \\
\hline Liberator Bolivar & $49,849.22$ \\
\hline Manglaralto & $49,117.60$ \\
\hline Montanita & $158,770.04$ \\
\hline little River & $14,285.60$ \\
\hline San Antonio & $20,590.25$ \\
\hline Total & $320,137.21$ \\
\hline
\end{tabular}

Table 6: Company collections.

\begin{tabular}{|l|r|}
\hline \multicolumn{2}{|c|}{ Collections over 40 years (USD) } \\
\hline Water consumption & $3,211,081.11$ \\
\hline Installation right & $147,765.67$ \\
\hline Installation and maintenance & $44,519.02$ \\
\hline Maintenance & $89,652.28$ \\
\hline Total & $3,493,018.09$ \\
\hline
\end{tabular}

Table 7: Estimate of salaries of members and non-members.

\begin{tabular}{|l|l|}
\hline \multicolumn{2}{|c|}{ Workers' salaries for 40 years (USD) } \\
\hline Total salary of affiliated workers & $434,396.68$ \\
\hline Total salary of unaffiliated workers & $519,339.48$ \\
\hline Total & $953,736.16$ \\
\hline
\end{tabular}

The cost estimate was made by obtaining data from the year 2020 and a weighting until the year 1981. The data are presented in Table 8 .

Profitability and profit estimation: In addition, the gross and net profitability of the company was analyzed, a value of $50 \%$ and $46 \%$ respectively was obtained. Gross profits amounting to USD 1,923,367.98 (Table 9). 
Table 8: Expenses generated over 40 years by the company.

\begin{tabular}{|l|r|}
\hline \multicolumn{2}{|c|}{ Expenses during the 40 years (USD) } \\
\hline Salary of affiliated workers & $434,396.68$ \\
\hline Salary of unaffiliated workers & $519,339.48$ \\
\hline Office supplies expenses & $59,990.03$ \\
\hline Water costs for the consumption of workers & $6,757.11$ \\
\hline Maintenance of wells and access roads & $88,521.91$ \\
\hline Transportation cost for procedures & $1,180.29$ \\
\hline Electric energy expenditure & $752,725.39$ \\
\hline Phone expense & $15,511.94$ \\
\hline Internet spending & $8,234.27$ \\
\hline Gasoline expense & $3,130.22$ \\
\hline Total & $1,889,787.32$ \\
\hline
\end{tabular}

Table 9: Profitability and utility of the company.

\begin{tabular}{|l|c|}
\hline \multicolumn{2}{|c|}{ Gross profit (USD) } \\
\hline Income & $3,813,155.30$ \\
\hline Expenses & $1,889,787.32$ \\
\hline Total & $1,923,367.98$ \\
\hline GROSS profitability & $50 \%$ \\
\hline NET profitability & $46 \%$ \\
\hline
\end{tabular}

\subsection{Global analysis}

Additionally, an analysis of strengths, opportunities, weaknesses, and threats-SWOT, of the Company was developed. The result is presented in Table 10.

The SWOT analysis, allowed to develop strategies for the development of JAAPMAN:

1. To sensitize the population about the responsible use of the water resource.

2. Make alliances with nearby water boards, national and international organizations that allow reducing water distribution problems in times of drought.

3. Address initiatives that allow obtaining national and international loans, to improve the productivity of the community enterprise.

4. Initiate automation processes of accounting systems to keep accounts updated and optimize economic and technical performance.

5. Exploit nationally and internationally to be a reference of efficient community management, the service provided is of quality.

6. Continue with the strategic alliances currently in force with Universities on issues of water management, geotourism, social aid, etc. 
Table 10: Analysis SWOT.

\begin{tabular}{|c|c|}
\hline \multicolumn{2}{|r|}{ SWOT analysis for JAAPMAN } \\
\hline \multirow{5}{*}{ 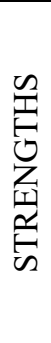 } & $\begin{array}{l}\text { Since } 1980 \text { JAAPMAN has supplied water for } 6 \text { communities in the Manglaralto } \\
\text { parish in an independent way. }\end{array}$ \\
\hline & $\begin{array}{l}\text { Managed by local users, under the principles of joint work and self-management, } \\
\text { with the support of users. }\end{array}$ \\
\hline & $\begin{array}{l}\text { It has generated important assets in its operating infrastructure with the effort of the } \\
\text { community. }\end{array}$ \\
\hline & In times of covid the service was not affected. \\
\hline & It continues to cany out works to improve the water supply service to the community. \\
\hline \multirow{3}{*}{ 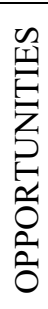 } & $\begin{array}{l}\text { They have agreements with universities and Res } \\
\text { studies and development of designs for new proje }\end{array}$ \\
\hline & $\begin{array}{l}\text { Surrounding tourism sector, allowing economic and social development through the } \\
\text { integral supply of water resources JAAPMAN is recognized nationally and } \\
\text { internationally for its good management of self-management. }\end{array}$ \\
\hline & onally for its good management of \\
\hline \multirow{4}{*}{ 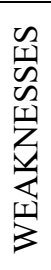 } & $\begin{array}{l}\text { Systematize files where you find passive information and documents, to improve } \\
\text { monitoring, maintenance, and expenses. }\end{array}$ \\
\hline & Little technical knowledge in administration areas. \\
\hline & $\begin{array}{l}\text { Lack of implementation of artificial recharge for supplying water to aquifers during } \\
\text { times of drought. }\end{array}$ \\
\hline & They do not have a desalination plant to deal with extreme drought situations. \\
\hline \multirow[t]{2}{*}{ 点 } & $\begin{array}{l}\text { There are plans to build a regional drinking water treatment plant that would end the } \\
\text { activities of the board and his } 40 \text { years of self-management, and the low prices that } \\
\text { they have, without a doubt, the new plant will have at higher costs. However, it could } \\
\text { also be viewed as an opportunity for the development of farming and not depend } \\
\text { only on tourism for sustenance, it could even be combined with the development of } \\
\text { farms and tourism, in development agroecological. }\end{array}$ \\
\hline & $\begin{array}{l}\text { There is the possibility that the Board will be managed by the public water company } \\
\text { that belongs to the central government. }\end{array}$ \\
\hline
\end{tabular}

\section{INTERPRETATION AND DISCUSSION}

It should be noted that the oldest structure (Well 1) dates from 1979 while wells 3B and 5B were built in 2020. Regarding the state of the pipes, they are considered to be in good condition, but in need of maintenance. The structure with the highest depreciation was the $300 \mathrm{~m}^{3}$ Manglaralto reservoir. Its value went from USD 67,635.83 to USD 4,319.90 (year 2020). The least depreciated structure was well 5B built in 2020 whose value increased from USD 24,781.62 with a current value of USD 24,317.41.

The analysis allowed to define the current total value for wells with USD depreciation 294,525.29 and with replacement value of USD 611,622.35, for the Manglaralto reservoirs with depreciation of USD 74,010.55, with replacement of USD 195,735.56, for the Montañita reservoirs with depreciation is USD 137,602.40, with replacement is USD 162,016.15, for the distribution networks of the six communes the value with depreciation is USD719,246.70, with replacement of USD 753,706.14, for the JAAPMAN headquarters with depreciation of 
USD125,542.97, with replacement of USD130,954.67 and for the docks a value with depreciation of USD103,334.23, with replacement of USD104,793.61. Giving a total of USD1,958,828.48

The inventory of the goods and estimated valuation, allowed to define a quantitative value to each one of the elements through the field visits, elaboration of detailed plans, making budgets with their respective depreciation calculations, where a considerable difference of approximately USD509,607.61 was obtained. This is due to the state of conservation of some wells, where the lack of preventive maintenance or abandonment was evidenced because the land was not their own. A total equity of USD 2,088,747.42 was obtained with a profit of approximately $50 \%$, this proves that despite the fact that the administrative and operational processes can be reviewed and improved, the joint management of 40 years has managed to supply vital fluid to more than 23,000 people, and in times of pandemic continue with the construction of new works such as 4 more wells, which are located on the two-sleeve road due to self-management.

From a methodological point of view, la preparation of the physical inventory, infrastructure, equipment, and machinery of the JAAPMAN, allowed community enterprise evaluated have a knowledge of the economic market value of all his patrimony built daily for 40 years. Although this work indeed focuses on financially valuing the investment and the total assets, it should be noted that this place is a natural laboratory, where several studiesinvestigations have been carried out, which is part of the know-how developed in this area. Even if it is not valued, it is an addition to all the investment in the sector.

Good governance in the water sector is associated with "integrated management" based on conservation and sustainable development [26]. JAAPMAN, with its participatory model [19] based on governance and administration by local people, delegates from each community and partners, show resilience to cope with population explosion, climate change, and tourism growth [15].

The SWOT analysis carried out provided a comprehensive analysis of the JAAPMAN and the definition of strategies to enhance the administrative management of the company. In addition, the evaluation of the results obtained allowed to have a real knowledge of the situation to tackle future improvement tasks and activities, the option to obtain credits and, fundamentally, to improve the management of the community company.

The traditional economic valuation (i.e., economical balance sheet) [2]-[4] of the evaluated community company has shown that, in addition to offering an efficient service (that are not provided in a timely manner by the state or a private company), it shows positive balance. Undoubtedly, community management could be considered an alternative form of governance of the natural resources of rural communities, as the case studied shows and other studies [9]-[11].

\section{CONCLUSIONS}

This research has made it possible to determine the patrimony of JAAPMAN, whose value reaches, to the date, approximately USD 2,088,747.42. This value is the result of work and effort of the community in the last 40 years. The valuation carried out reflects efficient and sustainable community management in drinking water service to the inhabitants. The community enterprise, in the last 40 years, He had an income of USD 3,813,155.30, with expenses of USD 1,889,787.32, which it is indicates a gross profitability of $50 \%$, which shows that the company by self-management has worked efficiently. In general, the assessment obtained indicates that the community company has been managed efficiently. In addition, the economical results allow the option of obtaining complementary financing and international support to improve future tasks as expansion of users receiving water resources, 
location of greater water reserves, recharge of aquifers, improvement of physical infrastructure-machinery and finally, staff training).

JAAPMAN is a community company that has given much more value to its work and infrastructure with the support of the university and its research. Although these values are not calculated here, it does leave the ethical challenge of recognizing a community's monumental work of supplying water for 40 years to its inhabitants.

\section{ACKNOWLEDGEMENT}

We express our gratitude to the Manglaralto Drinking Water Administration Board JAAPMAN.

\section{REFERENCES}

[1] Tarczyński, W., Tarczyńska-Łuniewska, M. \& Majewski, S., The value of the company and its fundamental strength. Procedia Computer Science, 176, pp. 26852694, 2020. DOI: 10.1016/j.procs.2020.09.331.

[2] Adams, C.A., Conceptualising the contemporary corporate value creation process. Accounting, Auditing and Accountability Journal, 30(4), pp. 906-931, 2017.

DOI: 10.1108/AAAJ-04-2016-2529.

[3] Bhullar, P.S. \& Bhatnagar, D., Theoretical framework: EV vs stock price - A better measurement of firm value. International Journal of Business and Management, 2(6), pp. 335-343, 2013.

[4] Copeland Thomas, T., Koller, E. \& Murrin, J., Valuation: Measuring and Managing the Value of Companies. John Wiley and Sons: New York, 1994.

[5] Berzkalne, I. \& Zelgalve, E., Intellectual capital and company value. Procedia Social and Behavioral Sciences, 110, pp. 887-896, 2014.

DOI: 10.1016/j.sbspro.2013.12.934.

[6] Gan, K. \& Saleh, Z., Intellectual capital and corporate performance of technologyintensive companies: Malaysia evidence. Asian Journal of Business and Accounting, 1(1), pp. 113-130, 2008.

[7] Frykman, D. \& Tolleryd, J., The Financial Times Guide to Corporate Valuation. Prentice Hall: London, 2012.

[8] Binswanger-Mkhize, J.P., de Regt, H.P. \& Spector, S., Local and Community Driven Development: Moving to Scale in Theory and Practice. World Bank Publications: Washington, DC, 2010.

[9] Feldman, T.R. \& Assaf, S., Social Capital: Conceptual Frameworks and Empirical Evidence. An Annotated Bibliography, The World Bank Social Capital Initiative: Washington, DC, 1999.

[10] Ostrom, E., Governing the Commons: The Evolution of Institutions for Collective Action. Cambridge University Press: Cambridge, 1990.

[11] Palerm Viqueira, T., Martínez Saldaña, J., Aventuras con el agua. La administración del agua de riego: historia y teoría. Colegio de Postgraduados: Montecillo, Texcoco, México, 2009.

[12] R. D. E. Asamblea Nacional Constituyente, Ley Orgánica de recursos hídricos, usos y aprovechamiento del agua. Quito-Ecuador, pp. 1-43, 2014.

[13] Arroyo Castillo, A.D.P., Análisis de los cambios normativos en el ámbito de la gestión de los recursos hídricos, planteados en la Constitución del 2008 y en la Ley de Aguas del 2014: a la luz de dos visiones de gestión, la pública y la comunitaria. Universidad Andina Simón Bolívar, Sede Ecuador, 2015. 
[14] Borbor Roca, A.G. \& Vera Mendoza, J.J., Estudio para la Optimización de la Distribución de Agua para Consumo Humano, por Parte de la Junta Regional de Manglaralto, Santa Elena, Ecuador, ESPOL, 2016.

[15] Herrera-Franco, G., Carrión-Mero, P., Aguilar-Aguilar, M., Morante-Carballo, F., Jaya-Montalvo, M. \& Morillo-Balsera, M. C., Groundwater resilience assessment in a communal coastal aquifer system. The case of Manglaralto in Santa Elena, Ecuador. Sustainability, 12(19), p. 8290, 2020. DOI: 10.3390/su12198290.

[16] Peel, M.C., Finlayson, B.L. \& McMahon, T.A., Updated world map of the KöppenGeiger climate classification. Hydrology and Earth System Sciences, 11(5), pp. 16331644, 2007. DOI: 10.5194/hess-11-1633-2007.

[17] García-Garizábal, I., Rainfall variability and trend analysis in coastal arid Ecuador. International Journal of Climatology, 37(13), pp. 4620-4630, 2017.

DOI: $10.1002 /$ joc. 5110 .

[18] Carrión-Mero, P. et al., Hydrochemical and isotopic characterization of the waters of the Manglaralto River Basin (Ecuador) to contribute to the management of the coastal aquifer. Water, 13(4), p. 537, 2021. DOI: 10.3390/w13040537.

[19] Herrera, G., Carrión, P. \& Alvarado, N., Participatory process for local development: Sustainability of water resources in rural communities: Case Manglaralto-Santa Elena, Ecuador. Handbook of Sustainability Science and Research. World Sustainability Series, eds L. F. W., Springer: Cham, pp. 663-676, 2018.

[20] Morante Carballo, F., Marcatoma Brito, L., Carrión Mero, P., Aguilar Aguilar, J.M. \& Ramírez, T., Urban wastewater treatment through a system of green filters in the Montañita commune, Santa Elena, Ecuador. WIT Transactions on Ecology and the Environment, 2019, pp. 233-249. DOI: 10.2495/WS190211.

[21] Carrión-Mero, P. Montalván, F. J., Morante-Carballo, F., Loor-Flores de Valgas, B., Apolo-Masache, C. \& Heredia, J., Flow and transport numerical model of a coastal aquifer based on the hydraulic importance of a dyke and its impact on water quality. Manglaralto-Ecuador. Water, 13(4), p. 443, 2021.

DOI: https://doi.org/10.3390/w13040443.

[22] Carrión, P., Herrera, G., Briones, J., Sánchez, C. \& Limón, J., Practical adaptations of ancestral knowledge for groundwater artificial recharge management of Manglaralto coastal aquifer, Ecuador. WIT Transactions on Ecology and the Environment, Sep. 2018, pp. 375-386. DOI: 10.2495/SDP180341.

[23] Herrera-Franco, G. et al., Geosites and georesources to foster geotourism in communities: Case study of the Santa Elena Peninsula Geopark Project in Ecuador. Sustainability, 12(11), p. 4484, 2020. DOI: 10.3390/su12114484.

[24] Franco, G. H., Quinchuelaa, T. G., Macancela, N. A. \& Mero, P. C., Participative analysis of socio-ecological dynamics and interactions a case study of the Manglaralto coastal aquifer, Santa Elena, Ecuador. Malaysian Journal of Sustainable Agriculture, 1(1), pp. 19-22, 2017. DOI: 10.26480/mjsa.01.2017.19.22.

[25] Parenti, P. et al., Pasantia como auxiliar de ingeniería: inspección de inmuebles urbanos y elaboración de informes de avalúos. Jurnal Sains dan Seni ITS, 6(1), pp. 5166, 2017.

[26] Rivière-Honegger, A. Traditional water management in the Mediterranean: Authorized union associations in Languedoc-Roussillon. Globalized Water, Springer Netherlands: Dordrecht, pp. 149-159, 2014. 